\title{
RANDOM AND SYSTEMATIC LAND USE/LAND COVER TRANSITIONS IN SEMI-ARID LANDSCAPES OF ETHIOPIAN CENTRAL RIFT VALLEY LAKES REGION (EAST AFRICA)
}

\author{
BeKele, B. ${ }^{1,2}-\mathrm{WU}, \mathrm{W} .{ }^{1,3^{*}}$ - Legesse, A. ${ }^{4}$-TeMESGEN, H. ${ }^{1,4}-$ YIRSAW, E. $^{4}$ \\ ${ }^{1}$ College of Land Management, Nanjing Agricultural University, Nanjing 210095, China \\ (e-mail: B. Bekele - belewbekele@yahoo.com, H.Temesgen-habte023@yahoo.com) \\ ${ }^{2}$ Department of Natural Resources Management, Assosa ATVET College, Assosa, Ethiopia \\ ${ }^{3}$ National and Local Joint Engineering Research Center for Rural Land Resources Use and \\ Consolidation, Nanjing 210095, China \\ ${ }^{4}$ Department of Natural Resources Management, Dilla University, Dilla, Ethiopia \\ (e-mail: A. Legesse-abiyottura@gmail.com,E.Yirsaw-eshetu.yirsaw@yahoo.com) \\ *Corresponding author \\ e-mail:ww@njau.edu.cn; phone: +86-137-7065-1675
}

(Received $3^{\text {rd }}$ Apr 2018; accepted $13^{\text {th }}$ Jun 2018)

\begin{abstract}
The analysis of land use/land cover (LULC) change has always been a topic of interest in land dynamics research. The majority of previous studies used the conventional method of "net change" analysis to show spatiotemporal LULC transitions. However, such analysis failed to indicate whether the transition is clearly systematic or due to an apparently random process. Hence, this study aimed to identify the most prominent signals of landscape transitions over the last three decades, using the landscapes of East African Rift Valley Region. We used Remote Sensing and GIS to quantify and map the changes in LULC for 1986 and 2016, and then the two maps compared to produce transition matrices. Results show that net change and swap change accounted for $43 \%$ and $57 \%$ of total change on the landscape respectively. Accordingly, $6 \%$ of scattered acacia woodland and 5\% of bush land have been converted to agricultural land, whereas $7 \%$ and $3 \%$ of scattered acacia woodland have been degraded towards grazing land and bush land respectively. These changes were found to be clearly systematic and hence indicate the dominant and prominent signals of landscape transformation. Hence, future land use policies need to consider such prominent signals of LULC change in order to plan an integrated approach to safeguard the fragile ecosystems of the region, while searching for alternative livelihood options.
\end{abstract}

Keywords: gain, loss, net change, persistence, swap change

\section{Introduction}

Anthropogenic-induced changes in land use/land cover (LULC) have occurred in the past, is presently ongoing, and is likely to continue in the future, with its related ecological, environmental and socioeconomic impacts worldwide (MEA, 2005; FAO, 2016). Unregulated LULC change for example has brought local, regional and global impact on biotic life, soil, hydrological balance, climate and ecological processes (Lambin et al., 2003; MEA, 2005; Yan et al., 2016; Rai et al., 2017). In addition, LULC change has threatened regional food supply, livelihood systems, and global sustainability (Reid et al., 2000). Such impacts of LULC change are more serious in developing countries where economic, political and sociocultural backgrounds further aggravate the complexity of the dynamics (Kalacska et al., 2017). These entire concerns make the analysis of land dynamics always been a topic of interest in researches at various fields and levels (Manandhar et al., 2010; Li et al., 2017; Yirsaw et al., 2017), 
which have spawned a flurry of research on its extent, drivers and consequences in recent decades globally.

Based on causative factors, the transitions in LULC could be classified as 'random' or 'systematic' (Pontius et al., 2004; Briones and Sepúlveda-Varas, 2017). Random transitions are those influenced by accidental or unique processes of change (Tucker et al., 1991; Geist and Lambin, 2002; Lambin et al., 2003). These transitions are usually caused by the interaction of land use factors such as: spontaneous migration, internal conflicts, changes in microeconomic conditions or loss of ownership to land resources (Lambin et al., 2003; Braimoh and Vlek, 2005). On the other hand, systematic transitions are those which occur due to regular or common processes of change. They tend to evolve in a consistent, progressive or gradual manner driven by natural population growth, increase in commercialization, border development, lack of public awareness on the environment or changes in institutions governing access to natural resources (Lambin et al., 2003; Geist et al., 2006).

Pontius et al. (2004) and Alo and Pontius Jr (2008) pointed out that though a conventional cross-tabulation matrix is a fundamental starting point in the analysis of LULC change, several related research works failed to analyze the matrix based on its various components, and thus failed to gain as much insight as possible concerning the potential processes that determine a pattern of landscape changes. This is because the majority of earlier landscape change studies used a 'net change' to compare a spatiotemporal LULC change trends between two different periods. However, though a net change indicates a definite change on the landscape, the absence of net change does not necessarily indicate the absence of change on the landscape. This is ascribed to the fact that the net change fails to capture a gross gain of a land category in one location with a gross loss of the same category in other location (Manandhar et al., 2010). This type of simultaneous loss and gain for a land category in spatial allocation is termed as the 'swapping' component of a change (Pontius et al., 2004; Braimoh, 2006; Briones and Sepúlveda-Varas, 2017). In addition, since the dominant landscape change signal is usually that of persistence, net change undermines the total change on the landscape, and hence fails to indicate the most prominent signals of LULC changes (Versace et al., 2008).

Due to such important limitations of 'net change', scientists recommend extending of the usual way of land transition matrices analysis beyond reporting net change, to gain an in-depth information that is important for detecting the most important signals of landscape changes (Braimoh, 2006; Manandhar et al., 2010). Pontius et al. (2004) strongly recommended detecting the most prominent signals of change, and ultimately linking pattern to process when analyzing LULC changes. Similarly, Geist et al. (2006) pointed the importance of considering two fundamental steps in any study of land dynamics. These are detecting changes in the landscape first, and then ascribing that change to some set of casual factors. The importance of addressing systematic and random LULC transitions has been further evidenced by recent studies (Burmeister and Schanze, 2016; Zewdie and Csaplovics, 2016; Briones and Sepúlveda-Varas, 2017). Linking the studies of changes in landscape pattern to the processes underlying helps to better understand the mechanisms of change; generate predictions about future rates of change, identify potential vulnerable places to change, and to design appropriate policy responses (Lambin, 1997; Nagendra et al., 2004; Alo and Pontius Jr, 2008).

Ethiopia is one of the typical countries in the sub-Saharan Africa confronted with the multidirectional impacts of extensive and rapid LULC dynamics since the beginning of the twentieth century (Kindu et al., 2013; Lemenih and Kassa, 2014). For example, 
empirical studies shown that deforestation in Ethiopian highlands has changed the landscape from $40 \%$ of forest cover in 1900 to $3.2 \%$ cover in 1980 (Dessie and Kleman, 2007; Eshetu, 2014), though some unpublished sources reported an increase in forest coverage of the country since 2000. On the other hand, significant increase in agricultural lands in expense of losses in forestlands, woodlands and grasslands has been reported in arid and semi-arid areas of the country including the Central Rift Valley (CRV) Lakes Region (Muzein, 2006; Garedew et al., 2009; Temesgen et al., 2013; Meshesha et al., 2014; Ariti et al., 2015; Zewdie and Csaplovics, 2016). In addition, in recent years, expansion in built-up areas has also been accelerated in Ethiopia since the government change and subsequent land use policy reforms in 1991 (Meire et al., 2013). Nonetheless, among such previous land dynamics studies in different parts of the country, only study by Zewdie and Csaplovics (2016) in north western Ethiopia, addressed random and systematic transition analysis. In addition, these studies did not emphasize the degree of landscape categories persistence relative to gross losses and gains. Hence, this study is aimed at: 1) detecting and mapping spatiotemporal LULC changes for the years 1986 and 2016; 2) analyzing LULC change matrices according to their various components (net change, persistence, gross gain/loss and swap); and 3) identifying systematic and random transitions, and the most prominent signals of LULC changes, and relating this to some possible causative factors, taking the CRV lakes region of Ethiopia as ideal case study site. This way of analysis helps in linking patterns to process and in designing appropriate policy interventions aimed at reducing the adverse effects of spectacular LULC changes in developing countries like East Africa.

\section{Materials and methods}

\section{The study area}

The study site, also known as Ziway-Shalla basin, is one of the four sub basins under the Rift Valley Lakes Basin, located about $170 \mathrm{~km}$ south of the capital city, Addis Ababa, Ethiopia. It is geographically found in the limits of $7^{\circ} 20^{\prime}-8^{\circ} 00^{\prime} \mathrm{N}$ latitude and $38^{\circ} 20^{\prime}-38^{\circ} 50^{\prime} \mathrm{E}$ longitude (Fig. 1). The study area belongs to the main African Rift system (Benvenuti et al., 2002). The African Rift originates from Aden Junction (Arabian Plate) in the Middle East and continues in the direction of south-west, traversing longitudinally eastern African countries such as Djibouti, Eritrea, Ethiopia, Kenya, Uganda, and Tanzania (JICA, 2012). The CRV is part of the Main Ethiopian Rift system (Molin and Corti, 2015) which is topographically characterized by a depression zone with steep marginal faults along its eastern and western edges (JICA, 2012). Altitude ranges from 1554 to $2069 \mathrm{~m}$ a.s.l. and bounded by north-western and south-eastern highlands (Hengsdijk and Jansen, 2006). The total area of the basin is about $13,401 \mathrm{~km}^{2}$ (JICA, 2012). It is situated in the current regional administrative boundaries of Southern Nations, Nationalities and Peoples (SNNP) and Oromia (Fig. 1).

The climate in CRV lakes region varies markedly with altitude and season (Jansen et al., 2007). It is characterized by warm and wet summer (June to September) and dry, cold and windy winter (October to May). The climate of the main valley in the central portion is dominantly semi-arid, whereas that of highland portion is sub-humid (Fritzsche et al., 2007). Based on the data obtained from National Meteorological Agency (NMA), Ziway Station, mean annual rainfall is about $739 \mathrm{~mm}$, while mean monthly minimum and maximum temperatures are 14 and $27{ }^{\circ} \mathrm{C}$ respectively (Fig. 2), 


$$
\text { - } 3996 \text { - }
$$

and this figure significantly varies throughout the basin depending on elevation. In general, the region is highly vulnerable to climate change as it encompasses a dryland zone which has been repeatedly hit by drought (Jansen et al., 2007; Biazin and Sterk, 2013).

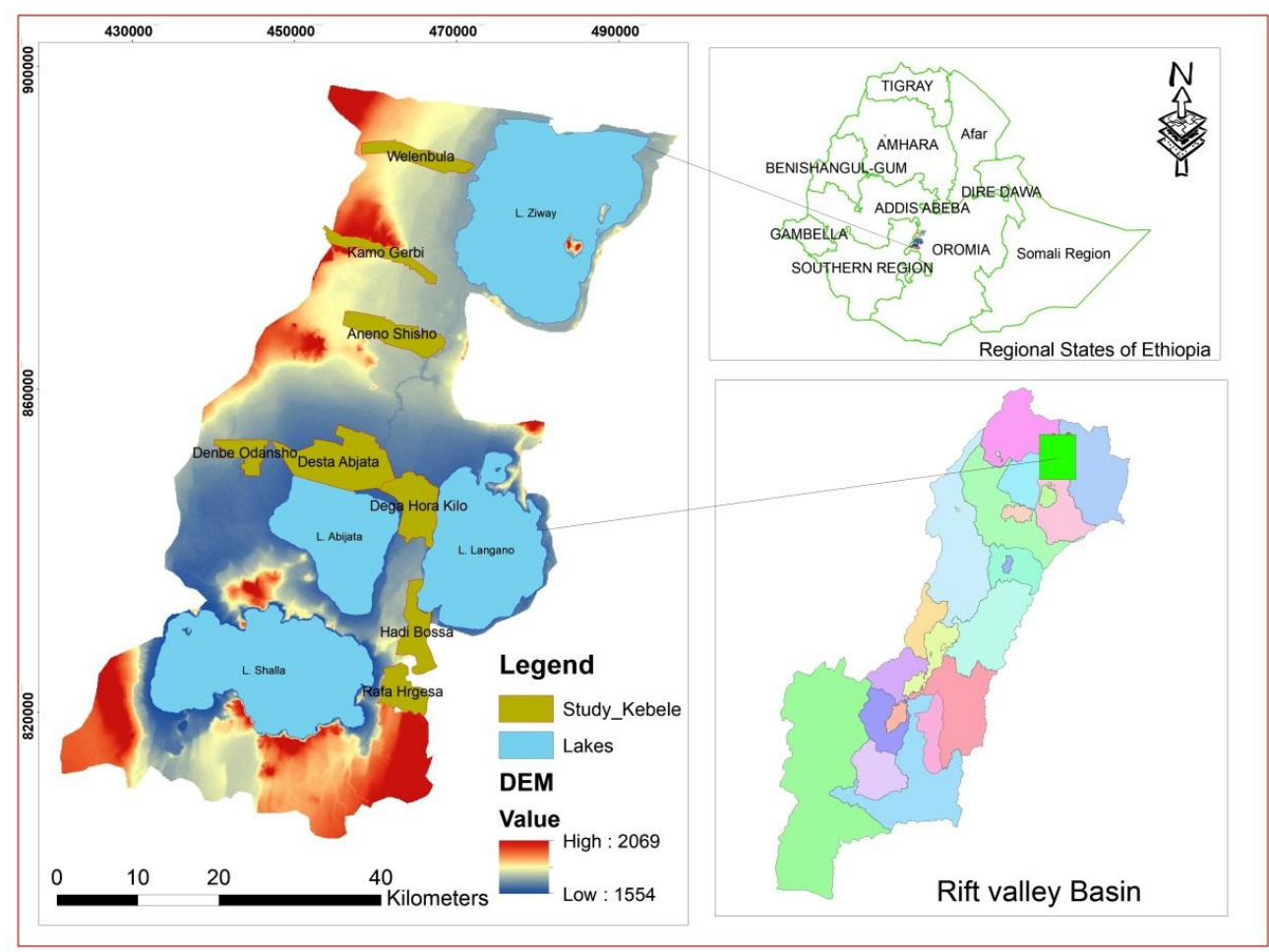

Figure 1. Location map of the study area: The map also indicates agro ecological areas and Kebeles (Villages), the lowest administrative units in Ethiopia, selected for households' socioeconomic survey

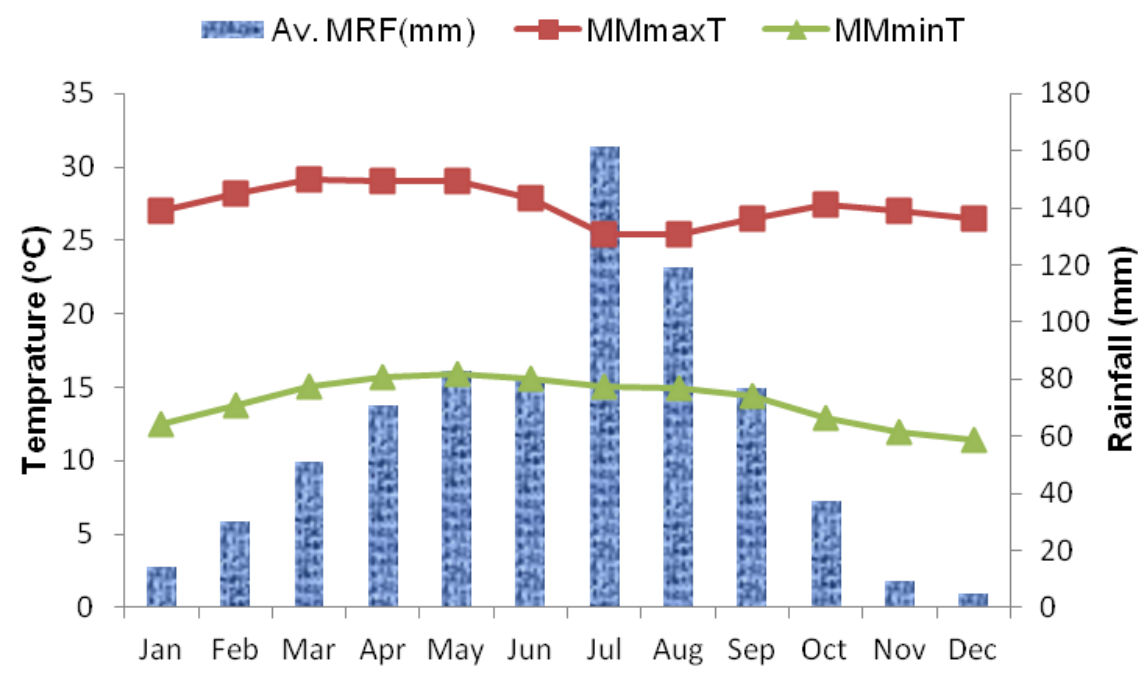

Months

Figure 2. Mean monthly maximum $\left(M M_{\max } T\right)$ and minimum $\left(M M_{\min } T\right)$ temperatures $\left({ }^{\circ} \mathrm{C}\right)$, and average monthly rainfall (MRF) distribution ( $\mathrm{mm})$ (1982-2017) at Ziway Meteorological Station. (Source: NMA) 
Soil in CRV lakes region is largely derived from recent volcanic rocks (Itanna, 2005). It is generally shallow in depth, and texture ranges between loamy sand and sandy loam that readily compacts and is susceptible to crusting, and also sensitive to drought (Biazin et al., 2011). The soil is weak in its physical structure (Abdelkadir and Yimer, 2011; Temesgen et al., 2013). Above all, the area is known for its highly fragile ecosystems subjected to high natural and anthropogenic-induced pressures. One of such human-induced pressures on environment among others in the region is the rapid changes in LULC.

Based on interpolation of 1994 and 2007 national census (CSA, 1994 and 2007), the total population for two Districts in the study area, namely Adami Tulu-Jido Kombolcha and Arsi Negele, is 155382 in 1986, 319484 in 2000 and 521124 in 2016, which indicates a sharp increase in population growth in the region. According to Melka et al. (2015), more than $85 \%$ of rural farmers in the study area mainly practice mixed farming, predominantly rain-fed, while the rest practice agro-pastoral livelihood system. The major field crops are maize, wheat, 'teff' (Eragrostis tef), barley, lentil, horse bean, chickpea and field pea (Hengsdijk and Jansen, 2006), whereas acacia woodland dominates the vegetation type of the region. Due to erratic nature of rainfall and poor farming system, agricultural productivity is still low and subsistent in the region (Garedew et al., 2009). With such highly variable climate and soil moisture stress, feeding the ever-growing population becomes a major challenge to government rural poverty reduction program in the region.

\section{Data sources}

Satellite imageries and field survey are the two main data sources used for this study (Table 1). For the purpose of temporal LULC change detection of 1986 and 2016, cloud-free Landsat5 Thematic Mapper (TM) and Landsat8 Operational Land Imager (OLI) imageries were respectively used after downloading from online United States Geological Survey (USGS) data base archive (http://glovis.usgs.gov). Satellite imagery from the same season of the year (January to February) was used to minimize discrepancies in reflectance caused by seasonal vegetation fluxes and sun angle differences. In addition, Google earth service, topographic map and administrative map of the study area were used for boundary delineation, navigation purpose, support in ground truthing and training site establishment.

Table 1. Data used and sources

\begin{tabular}{c|c|c|c}
\hline Data source & Path/Row & Resolution & $\begin{array}{c}\text { Analysis period and } \\
\text { date of acquisition }\end{array}$ \\
\hline Landsat5 Thematic Mapper (TM) & $168 / 055$ & $30 \mathrm{~m}$ & $1986(21 / 01 / 1986)$ \\
Landsat8 Operational Land Imager (OLI) & $168 / 055$ & $30 \mathrm{~m}$ & $2016(04 / 02 / 2016)$ \\
Aster Global Digital Elevation Model (ASTGM) & & & 2016 \\
Topographic map/sheet (EMA) Scale:1: 250000 & & & 2017 (1986-2016) \\
Google Earth/varying resolution & & & Field work in 2017 \\
Sketch map/GCPs/Ground observation/Key \\
informants
\end{tabular}


Field survey was carried out from January to May 2017 to collect information about households' socioeconomic background, historical LULC change, driving forces, impacts and adaptation strategies of farmers who were knowledgeable about LULC dynamics during the respective study period (1986-2016). Focus group discussions with five to ten participants per group were carried out in a total of eight Kebeles (Villages) randomly selected from two adjacent study Woredas (Districts) (five at Adami TuluJido Kombolcha District and three at Arsi Negele District) (Fig. 1). Additional land use information also gathered from at least one elder key informant (age at least 60) from each village. Ground control points (GCP) were collected through interpretation of topographic map, Google earth, focus group discussion/key informants' interview, and visual observation carried out during field verification.

\section{Image processing and LULC classification}

Landsat images were pre-processed for geometric and atmospheric corrections using $30 \mathrm{~m}$ by $30 \mathrm{~m}$ Aster Global Digital Elevation Model (ASTGM) of the study area, and the commonly used dark subtraction technique respectively (Jensen, 1996). Each image was georectified to Universal Transverse Mercator (UTM) WGS 1984 Zone 37 North coordinates using ground control points collected during field work (Hall et al., 1991; Wijedasa et al., 2012). A first-order affine transformation and nearest-neighbour resampling method was applied for LULC classification (Jensen, 1996), resulting in a root mean square error (RMSE) below $15 \mathrm{~m}$ for all Landsat images. The procedure involved radiometric rectification of the 1986 image to the 2016 image, followed by a tasseled cap orthogonal transformation of the original six bands in each image in to three new dimensional spaces, corresponding to soil brightness, green vegetation and moisture indices (Hall et al., 1991). Apart from yielding relevant training data for LULC classification, the transformation also improved visual discrimination of LULC types. Ground-truth GPS points recorded in the field were used for training of the 2016 imagery, to determine the LULC classes during the image classification process, and to assess the accuracy of the classification.

LULC classification was carried out using the supervised maximum likelihood algorithm approach which is generally recognized as the popular classifier technique (Booth and Oldfield, 1989; Liu and Zhou, 2004; Verburg et al., 2004; Lillesand et al., 2014). It requires prior knowledge of the area to set training sites and use of spectral information contained in individual pixels to generate LULC classes. Accordingly, we classified the LULC categories of the study area into: dense and scattered acacia woodlands, grass/grazing land, agricultural land, shrub/bush land, water body, marsh/swampy area and bare land. The operational definition of each LULC category is given in Table 2.

Accuracy assessment was done using a separate set of points randomly generated using a stratified random sampling approach to determine the precision of the classified image (Jensen, 1996) which is important for post-classification change detection analysis (Liu and Zhou, 2004). The reference points were transferred to a GIS software program, in which they were overlaid with the classified images. A field check was made to test the accuracy of the reference points. The accuracy of a classification was assessed by comparing the classification with some reference data that was believed to reflect accurately the true LULC classes. The overall accuracy was measured by counting the number of pixels classified consistently in the satellite image and on the ground and dividing this by the total number of sample pixels in each class. The post- 
classification comparison (PCC) change detection technique was used for change detection analysis (Jensen, 1996). This was done by comparison of independently produced classified images, by properly coding the classification results of 1986 and 2016, from which a change map that indicates a complete matrix of change was produced (Singh, 1989). Actual change was obtained by a direct comparison between classified image from 1986 with that obtained for 2016 and results described by LULC change in percentage.

Table 2. Operational definitions of different LULC types of CRV lakes region of Ethiopia

\begin{tabular}{|c|c|}
\hline LULC type & General description \\
\hline $\begin{array}{l}\text { Dense acacia } \\
\text { woodland }\end{array}$ & $\begin{array}{l}\text { Acacia dominated woodlands where the trees cover approximately more than } 40 \% \\
\text { of the ground surface. It also includes other dense broad-leaved tress like riverine } \\
\text { forests and plantations }\end{array}$ \\
\hline $\begin{array}{l}\text { Scattered acacia } \\
\text { woodland }\end{array}$ & $\begin{array}{l}\text { Acacia dominated woodlands where the trees cover approximately between } 10-40 \% \\
\text { of the ground surface and the open areas under the tree canopy covered with grasses } \\
\text { and herbs }\end{array}$ \\
\hline Agricultural land & $\begin{array}{l}\text { Areas used for rain-fed and irrigated cultivation (small or large scale, seasonal or } \\
\text { perennial), including fallow plots and a complex unit, i.e. cultivated land mixed } \\
\text { with bushes, trees and rural homesteads }\end{array}$ \\
\hline Grass/grazing land & $\begin{array}{c}\text { Grass being the dominant plants with the canopy of scattered acacia trees } \\
\text { approximately covering less than } 10 \%\end{array}$ \\
\hline Water body & Lakes, reservoirs/ponds, rivers and streams \\
\hline $\begin{array}{l}\text { Swampy/marshy } \\
\text { land }\end{array}$ & $\begin{array}{l}\text { Permanently waterlogged areas covered by long grasses, other aquatic plants, and } \\
\text { mainly found near lakes and river banks }\end{array}$ \\
\hline Bush/shrub land & $\begin{array}{l}\text { Land covered by scattered small trees, bushes and shrubs (less than } 5 \mathrm{~m} \text { in height) } \\
\text { and occasionally found mixed with grass }\end{array}$ \\
\hline Bare land & $\begin{array}{l}\text { Surface not covered by any type of vegetation, mainly including: sands, rock } \\
\text { outcrops, cattle tracks, or exposed soils not used by any of the above LULC types }\end{array}$ \\
\hline
\end{tabular}

\section{The LULC transition matrix}

For the simplicity of explanation of the analysis methods used for LULC transition in this study, the general cross-tabulation matrix for comparison of two maps from two different points in time (1986 and 2016) was adopted from the initial work of Pontius et al. (2004). In a cross-tabulation matrix, the rows display the classes of 1986 and the columns display the classes of 2016. Entries on the diagonal indicate 'persistence', proportion of the landscape that did not undergo change during 1986-2016, and it usually dominates most landscape changes (Pontius et al., 2004). Persistence helps to compute two types of changes: gross gains and gross losses (Pontius et al., 2004). The gains are the differences between the column totals and persistence, whereas losses are the differences between row totals and persistence.

\section{LULC persistence, net change and swap}

Persistence is simply the proportion of the landscape that did not undergo change during the respective study period, represented by entries on the diagonal of a crosstabulation matrix. Swap, as elaborated by Pontius et al. (2004), is a change attributed to location which implies simultaneous gain and loss of a land class on the landscape. Thus, the computation of swap requires the pairing of each pixel that loses with a pixel 
those gains. The amount of swap $\left(S_{j}\right)$ of land class $\mathrm{j}$ is defined as two times the minimum of the gain and the loss (Eq. 1) as in Pontius et al. (2004).

For each class $\mathrm{j}$ in cross-tabulation matrix, the absolute value of net change during 1986-2016 is simply calculated as $\left|\mathrm{C}_{+\mathrm{j}}-\mathrm{C}_{\mathrm{j}+}\right|$. Equation 2 defines the absolute value of the net change, denoted $\mathrm{N}_{\mathrm{j}}$, for class $\mathrm{j}$ as the maximum of the gain and loss minus the minimum of the gain and loss (Braimoh, 2006). This net change is the remaining unpaired gain or loss after all gains and losses have been paired to compute the amount of swap. Equation 3 shows that one can express total change $\left(\mathrm{T}_{\mathrm{j}}\right)$ for each category as either the sum of the net change and swap or the sum of the gains and losses as in Pontius et al. (2004) and Braimoh (2006).

$$
\begin{gathered}
S_{i}=2 \min \left(C_{i+}-C_{i j}, C_{+i}-C_{i j}\right) \\
\mathrm{N}_{\mathrm{j}}=\operatorname{Max}\left(\mathrm{C}_{\mathrm{j}+}-\mathrm{C}_{\mathrm{jj}}, \mathrm{C}_{+\mathrm{j}}-\mathrm{C}_{\mathrm{ji}}\right)-\operatorname{Min}\left(\mathrm{C}_{\mathrm{j}+}-\mathrm{C}_{\mathrm{jj}}, \mathrm{C}_{+j}-\mathrm{C}_{\mathrm{jj}}\right)=\left|\mathrm{C}_{+j}-\mathrm{C}_{\mathrm{j}+}\right| \\
\mathrm{T}_{\mathrm{j}}=\mathrm{D}_{\mathrm{j}}+\mathrm{S}_{\mathrm{j}}=\operatorname{Max}\left(\mathrm{C}_{\mathrm{j}+}-\mathrm{C}_{\mathrm{jj}}, \mathrm{C}_{+\mathrm{j}}-\mathrm{C}_{\mathrm{jj}}\right)+\operatorname{Min}\left(\mathrm{C}_{\mathrm{j}+}-\mathrm{C}_{\mathrm{jj}}, \mathrm{C}_{+\mathrm{j}}-\mathrm{C}_{\mathrm{jj}}\right)
\end{gathered}
$$

In addition to these indices of land change, other important indicators of LULC vulnerability to transition (Ouedraogo et al., 2011; Zewdie and Csaplovics, 2016) like: gross loss to persistence ratio (1/p) which assesses the exposure of a land cover for a change, gross gain to persistence ratio $(\mathrm{g} / \mathrm{p})$ which evaluates the gain of land cover in comparison to its 1986 size, net change to persistence ratio $(\mathrm{n} / \mathrm{p})$, the tendency of land classes to undergo change, and gain to loss ratio (g/l) were analyzed based on baseline data in in cross-tabulation matrix.

\section{Identification of dominant signals of LULC changes}

Even though the analysis of persistence, swap, gross gain and gross loss is very important, still it fails to inform whether systematic transitions exist or not among the land classes, as this general analysis fails to examine the dynamics among the offdiagonal entries of cross-tabulation matrix. In other words, it fails to identify the dominant signals of land change. To relate the concept of 'random' and 'systematic' LULC transitions to land change transition matrix, it is important to define the terms in terms of statistical concept of Chi-square test as explained by Pontius et al. (2004). Statistically, a landscape transition is said to be 'random' if a LULC class gains from other categories in proportion to the availability of those other losing classes, or if a class loses to other class in proportion to the size of those other gaining classes (Pontius et al., 2004; Braimoh, 2006; Versace et al., 2008; Ouedraogo et al., 2011), and any large deviation from these proportions is referred to as 'systematic' transitions.

The identification of systematic inter-category transitions generally consists of four steps. The first step computes the expected gain, $\mathrm{g}_{\mathrm{ij}}$ for each class under a random process of gain using the formula given in Equation 4 (Pontius et al., 2004). Equation 4 assumes that the gain of each class and the proportion of each class in 2016 are given a priori. The gain is then distributed in each column among the off-diagonal entries in the column according to their relative proportions in 1986. This makes the gain fairly random.

$$
\mathrm{B}_{\mathrm{ij}}=\left(\mathrm{C}_{+\mathrm{j}}-\mathrm{C}_{\mathrm{jij}}\right)\left(\frac{\mathrm{C}_{\mathrm{i}+}}{100-\mathrm{C}_{\mathrm{i}+}}\right), \forall \mathrm{\forall i} \neq \mathrm{j}
$$


The second step computes the differences between the observed proportions and the expected proportions under a random process of gain (Pontius et al., 2004). Large positive or negative deviations from zero indicate systematic inter-category transitions rather than random transitions occurring between two LULC classes. The higher a positive difference between the observed proportion and the expected proportion under a random process of gain for the transition between class 1 and class 2 , the larger the area affected by systematic gain of 2 from 1 . The higher a negative difference between the observed proportion and the expected proportion under a random process of gain for the transition between class 1 and 2, the higher the tendency of class 2 to avoid gaining systematically from class 1 .

The third step computes the expected loss, $1_{\mathrm{ij}}$ under a random process of loss using the formula in Equation 5 (Pontius et al., 2004). Equation 5 assumes the loss of each class is fixed, and distributes the loss in each row across the other classes relative to their proportions in 2016. The fourth and the last step compute the differences between the observed and the expected proportions under a random process of loss (Pontius et al., 2004). Similarly, large positive and negative deviations from zero indicate systematic inter-category transitions rather than random transitions occurring between two LULC types. In general, according to Alo and Pontius Jr (2008), to arrive at a conclusive evidence of a dominant signal of landscape transformation, class 1 must systematically gain from class 2 , and class 2 must systematically lose to class 1 simultaneously.

$$
\mathrm{l}_{\mathrm{ij}}=\left(\mathrm{C}_{\mathrm{i}+}-\mathrm{C}_{\mathrm{ii}}\right)\left(\frac{\mathrm{C}_{+\mathrm{j}}}{100-\mathrm{C}_{+\mathrm{i}}}\right), \forall \mathrm{Bi} \neq \mathrm{j}
$$

\section{Results}

\section{Accuracy assessment}

Results of the overall classification accuracy, producer accuracy, user accuracy and kappa statistics for each LULC class, derived from the error matrix, were used to determine the degree of accuracy of the LULC classification (Table 3). The lowest producer accuracy of $61 \%$ and $60 \%$ were obtained for bare land and swampy/marsh land classes for 1986 and 2016 respectively. On the other hand, an overall accuracy of greater than $90 \%$ was obtained for both study periods which could be acceptable for proceeding to further data analysis in this study. The lowest producer accuracy assessment value obtained for bare land in 1986 could be due to classification error with grazing land, as both could share similar spectral signature especially in arid landscapes (Zhang et al., 2015). Similarly, it is difficult to differentiate between swampy and water body, and scattered and dense acacia woodlands in some circumstances due to absence of clear cut boundaries between these classes which could also be possible source of classification error.

\section{Major LULC transitions}

From the analysis of results, we observed an increase in human pressure and a decrease in natural and semi-natural landscapes in CRV lakes region of Ethiopia. Spatiotemporal pattern of LULC change in the study area for 1986 and 2016 is shown in Figure 3, while Table 4 summarizes the 1986 and 2016 proportion, gain, loss, swap, net 
change and total change of each LULC class. The largest portion of the landscape has been covered by water body in both 1986 (31\%) and 2016 (29\%), whereas dense acacia woodland and swampy/marshy land covered the least percentage $(<3 \%)$ during both periods.

Table 3. Accuracy assessment results of LULC classification

\begin{tabular}{c|c|c|c|c}
\hline \multirow{2}{*}{ LULC type } & \multicolumn{2}{|c|}{ 1986 } & \multicolumn{2}{c}{$\mathbf{2 0 1 6}$} \\
\cline { 2 - 5 } & Producer accuracy & User accuracy & Producer accuracy & User accuracy \\
\hline Agricultural land & 88.24 & 85.71 & 90.20 & 93.88 \\
Scattered acacia woodland & 100.00 & 96.36 & 95.65 & 91.67 \\
Bare land & 61.11 & 84.62 & 76.92 & 83.33 \\
Bush/Shrub land & 92.59 & 80.65 & 94.12 & 80.00 \\
Dense acacia woodland & 75.00 & 90.00 & 66.67 & 66.67 \\
Grass/Grazing land & 75.86 & 75.86 & 96.77 & 92.31 \\
Swampy/Marshy land & 90.91 & 90.91 & 60.00 & 85.71 \\
Water body & 100.00 & 100.00 & 97.40 & 98.68 \\
\hline Overall accuracy & \multicolumn{2}{|c|}{90.63} & \multicolumn{2}{c}{0.91} \\
Kappa Statistics & 0.89 & & 92.58 \\
\hline
\end{tabular}

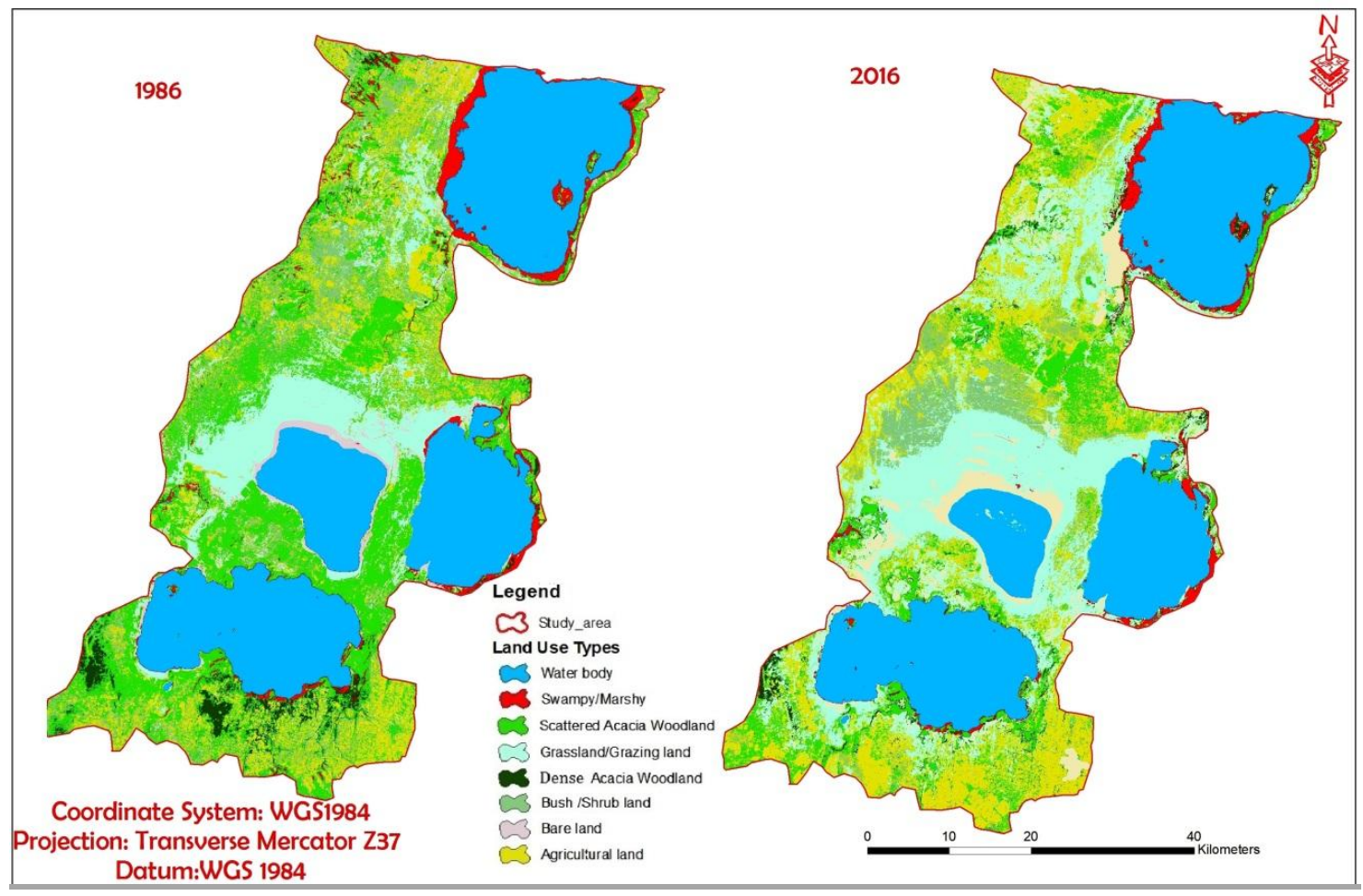

Figure 3. LULC maps for the years 1986 and 2016

Over the last three decades, grass/grazing land, agricultural land and bare land have increased by $124 \%, 42 \%$ and $34 \%$ respectively, whereas scattered acacia woodland, bush/shrub land and swampy/marshy land have declined by 52\%, 50\% and $31 \%$ respectively (Table 4). Scattered acacia woodland, which was the second in terms of 
proportion in $1986(23 \%)$, declined by about half percentage in $2016(11 \%)$. Due to this, scattered acacia woodland experienced the highest area loss (18\%) followed by bush/shrub land (11\%) during the same period. On the other hand, grazing land, which was only $11 \%$ in 1986, has shown an increment and took the second position in terms of area percentage proportion in $2016(25 \%)$. Hence, grazing land experienced the highest gain in over $17 \%$ of the landscape followed by agricultural land (14\%) during the study period. The gain-to-loss ratio was also highest (5.2) for grazing land, indicating that grazing land experienced five times more gain than loss. In general, total change occurred in about $48 \%$ of the landscape during the study period while the rest, $52 \%$, persisted (Table 4).

Table 4. Landscape changes (\%)

\begin{tabular}{|c|c|c|c|c|c|c|c|c|}
\hline LULC types & $\begin{array}{l}\text { Total } \\
1986\end{array}$ & $\begin{array}{l}\text { Total } \\
2016\end{array}$ & Persistence & Gain & Loss & $\begin{array}{c}\text { Total } \\
\text { change }\end{array}$ & Swap & $\begin{array}{c}\text { Absolute } \\
\text { value of } \\
\text { net } \\
\text { change }\end{array}$ \\
\hline Agricultural land & 13.94 & 19.85 & 6.15 & 13.70 & 7.79 & 21.50 & 15.59 & 5.91 \\
\hline $\begin{array}{l}\text { Scattered acacia } \\
\text { woodland }\end{array}$ & 22.87 & 11.08 & 5.15 & 5.93 & 17.72 & 23.65 & 11.86 & 11.79 \\
\hline Bare land & 3.79 & 5.08 & 0.59 & 4.50 & 3.21 & 7.71 & 6.41 & 1.29 \\
\hline Bush/Shrub land & 11.90 & 5.92 & 1.20 & 4.72 & 10.70 & 15.42 & 9.43 & 5.98 \\
\hline $\begin{array}{l}\text { Dense acacia } \\
\text { woodland }\end{array}$ & 2.48 & 2.23 & 0.50 & 1.73 & 1.97 & 3.70 & 3.45 & 0.25 \\
\hline Grass /Grazing land & 11.06 & 24.81 & 7.76 & 17.05 & 3.30 & 20.35 & 6.60 & 13.76 \\
\hline Swampy/Marshy land & 2.99 & 2.07 & 1.44 & 0.62 & 1.54 & 2.17 & 1.24 & 0.92 \\
\hline Water body & 30.97 & 28.96 & 28.80 & 0.16 & 2.17 & 2.34 & 0.32 & 2.01 \\
\hline Total & 100.00 & 100.00 & 51.59 & 48.41 & 48.41 & 48.41 & 27.45 & 20.96 \\
\hline
\end{tabular}

\section{Net change and swap changes}

Results showed both swap changes and net changes occurred for most of LULC categories in the study area. The summary for changes attributed to net change and swap is given in Table 4. Changes in all land categories except for water body consists both swap and net changes, whereas change in dense acacia woodland is nearly a pure swap type. This is to mean that for dense acacia woodland the net change is zero, and hence each cell gained can be paired with each cell lost. The change attributed to quantitative net change is highest for grazing land (about $68 \%$ of total change for grazing land); followed by scattered acacia woodland (about $50 \%$ of its total change). Net change overall accounted for $43 \%$ of total change on the landscape. On the other hand, the change attributed to location (swap) is highest for agricultural land (72\% of total change for its whole area), followed by scattered acacia woodland (50\% of its total change). Swap of land change dynamics overall accounted for $57 \%$ of total landscape change in the study area.

\section{Persistence of LULC classes}

We observed all LULC categories showed relative persistence during the study period which is in consistent with the usual trend in most LULC change studies. About 
$52 \%$ of landscape remained unchanged during the study period (Fig. 4 and Table 4). The proportion of different LULC classes that were unchanged between 1986 and 2016 are also shown in the diagonal cells of Table 5. Water body experienced the highest resistance to change during the study period. About $93 \%$ of landscape occupied by water body in 1986 remained unchanged in 2016.

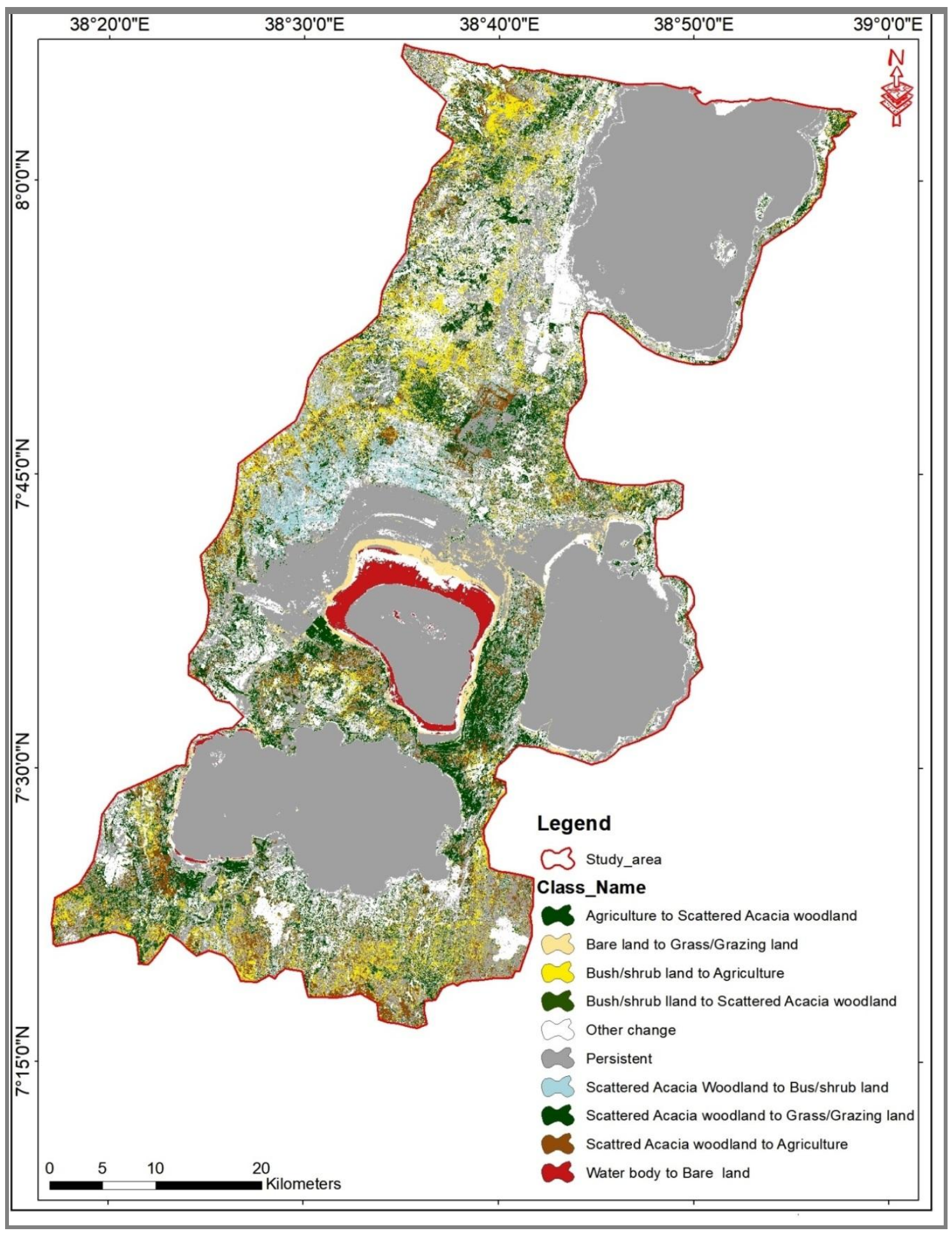

Figure 4. Map for major LULC transitions and persistence (1986-2016) 
Table 5. LULC transition matrix for 1986-2016 (\%)

\begin{tabular}{c|c|c|c|c|c|c|c|c|c|c}
\hline \multirow{2}{*}{1986} & \multicolumn{10}{|c}{$\mathbf{2 0 1 6}$} \\
\cline { 2 - 11 } & AL & SA & BL & BS & DA & GL & SM & WB & Total 1986 & Loss \\
\hline Agricultural land (AL) & 6.15 & 2.42 & 0.62 & 1.20 & 0.17 & 3.35 & 0.03 & 0.00 & 13.94 & 7.79 \\
Scattered acacia woodland (SA) & 6.26 & 5.15 & 0.97 & 2.55 & 1.06 & 6.69 & 0.20 & 0.00 & 22.87 & 17.72 \\
Bare land (BL) & 0.56 & 0.28 & 0.59 & 0.08 & 0.04 & 2.21 & 0.04 & 0.00 & 3.79 & 3.21 \\
Bush/Shrub land (BS) & 5.05 & 1.97 & 0.58 & 1.20 & 0.13 & 2.94 & 0.03 & 0.00 & 11.90 & 10.70 \\
Dense acacia woodland (DA) & 0.63 & 0.55 & 0.06 & 0.05 & 0.50 & 0.56 & 0.12 & 0.00 & 2.48 & 1.97 \\
Grass/Grazing land (GL) & 1.03 & 0.43 & 0.96 & 0.82 & 0.04 & 7.76 & 0.02 & 0.00 & 11.06 & 3.30 \\
Swampy/Marshy land (SM) & 0.17 & 0.26 & 0.09 & 0.01 & 0.28 & 0.57 & 1.44 & 0.16 & 2.99 & 1.54 \\
Water body (WB) & 0.00 & 0.01 & 1.22 & 0.00 & 0.02 & 0.74 & 0.18 & 28.80 & 30.97 & 2.17 \\
Total 2016 & 19.85 & 11.08 & 5.08 & 5.92 & 2.23 & 24.81 & 2.07 & 28.96 & 100.00 & 48.41 \\
Gain & 13.70 & 5.93 & 4.50 & 4.72 & 1.73 & 17.05 & 0.62 & 0.16 & 48.41 & \\
\hline
\end{tabular}

Bush/shrub land on the other hand showed the lowest persistence in $1.20 \%$ of the landscape. As shown in Table 6, the loss-to-persistence ratio (1/p) for all classes is greater than 1 except for grazing land and water body. This indicates all land classes except grazing land and water body showed a higher tendency to lose than to persist. The highest (8.88) and lowest (0.08) $1 / \mathrm{p}$ ratio was obtained for bush/shrub land and water body classes respectively. On the other hand, the gain-to-persistence ratio $(\mathrm{g} / \mathrm{p})$ is greater than 1 for all classes except aquatic habitats (Table 6), indicating that these land classes experienced more gain than persistence. Bare land experienced the highest $\mathrm{g} / \mathrm{p}$ ratio (7.68), whereas water body and swampy/marshy lands experienced the least values.

Table 6. Gain to persistence ( $g / p)$, loss to persistence $(l / p)$, net change to persistence $(n / p)$ and gain to loss $(\mathrm{g} / \mathrm{l})$ ratios of $L U L C$ classes

\begin{tabular}{c|c|c|c|c}
\hline LUC class & $\begin{array}{c}\text { Gain to persistence } \\
(\mathbf{g} / \mathbf{p})\end{array}$ & $\begin{array}{c}\text { Loss to } \\
\text { persistence }(\mathbf{l} / \mathbf{p})\end{array}$ & $\begin{array}{c}\text { Net change to } \\
\text { persistence }(\mathbf{n} / \mathbf{p})\end{array}$ & $\begin{array}{c}\text { Gain to loss } \\
(\mathbf{g} / \mathbf{l})\end{array}$ \\
\hline Agricultural land & 2.23 & 1.27 & 0.96 & 1.76 \\
Scattered acacia woodland & 1.15 & 3.44 & -2.29 & 0.33 \\
Bare land & 7.68 & 5.47 & 2.20 & 1.40 \\
Bush/Shrub land & 3.92 & 8.88 & -4.97 & 0.44 \\
Dense acacia woodland & 3.43 & 3.92 & -0.49 & 0.87 \\
Grass /Grazing land & 2.20 & 0.43 & 1.77 & 5.17 \\
Swampy/Marshy land & 0.43 & 1.07 & -0.64 & 0.40 \\
Water body & 0.01 & 0.08 & -0.07 & 0.07 \\
\hline
\end{tabular}

\section{Systematic and random LULC transitions}

Results have clearly showed that systematic as well as random LULC transitions occurred in the study area during 1986 to 2016. In Table 7a, the off-diagonal numbers 
represent expected values of the gain in LULC categories at the given persistence under a random process of change. The difference between the observed proportions (Table 5) and the expected proportions (Table $7 a$ ) is given in Table $7 b$. The observed value for gain is greater than the corresponding expected value for all land classes except for swampy and water body (Fig. 5). Relatively large positive values in Table $7 b$ indicates systematic gain transitions. Hence, agricultural land systematically gained from both bush land (3.16\%) and scattered acacia wood land (2.62\%) transitions. Similarly scattered acacia woodland gained systematically from both agricultural land $(1.35 \%)$ and bush land $(1.05 \%)$ transitions. In addition, grazing land systematically gained from both scattered acacia woodland $(2.30 \%)$ and bare land $(1.48 \%)$. Bush land also systematically gained from scattered acacia wood land $(1.33 \%)$. On the other hand, grazing land, agricultural land, scattered acacia woodland and bush land, all systematically avoided gaining from water bodies (indicated by large negative values in Table $7 b$ ), which also mean that water body avoided systematically losing to these LULC categories.

Table 7. LULC transition matrix for inter-class gains

\begin{tabular}{|c|c|c|c|c|c|c|c|c|c|c|}
\hline \multirow[b]{2}{*}{1986} & \multicolumn{10}{|c|}{2016} \\
\hline & $\mathbf{A L}$ & SA & BL & BS & DA & GL & SM & WB & $\begin{array}{l}\text { Total } \\
1986\end{array}$ & Loss \\
\hline \multicolumn{11}{|c|}{ (a) Expected gains under a random process of gain (\%) } \\
\hline Agricultural land (AL) & 6.15 & 1.07 & 0.65 & 0.75 & 0.25 & 2.67 & 0.09 & 0.03 & 11.66 & 5.51 \\
\hline $\begin{array}{l}\text { Scattered acacia } \\
\text { woodland (SA) }\end{array}$ & 3.64 & 5.15 & 1.07 & 1.22 & 0.40 & 4.39 & 0.15 & 0.05 & 16.07 & 10.93 \\
\hline Bare land (BL) & 0.60 & 0.29 & 0.59 & 0.20 & 0.07 & 0.73 & 0.02 & 0.01 & 2.51 & 1.93 \\
\hline Bush/Shrub land (BS) & 1.90 & 0.91 & 0.56 & 1.20 & 0.21 & 2.28 & 0.08 & 0.03 & 7.17 & 5.96 \\
\hline $\begin{array}{l}\text { Dense acacia woodland } \\
\text { (DA) }\end{array}$ & 0.39 & 0.19 & 0.12 & 0.13 & 0.50 & 0.47 & 0.02 & 0.01 & 1.83 & 1.33 \\
\hline Grass/Grazing land (GL) & 1.76 & 0.85 & 0.52 & 0.59 & 0.20 & 7.76 & 0.07 & 0.03 & 11.77 & 4.01 \\
\hline $\begin{array}{l}\text { Swampy/Marshy land } \\
\text { (SM) }\end{array}$ & 0.48 & 0.23 & 0.14 & 0.16 & 0.05 & 0.57 & 1.44 & 0.01 & 3.08 & 1.64 \\
\hline Water body & 4.93 & 2.38 & 1.45 & 1.66 & 0.55 & 5.94 & 0.20 & 28.80 & 45.90 & 17.10 \\
\hline Total 2 & 19.85 & 11.08 & 5.08 & 5.92 & 2.23 & 24.81 & 2.07 & 28.96 & 100.00 & 48.41 \\
\hline Gain & 13.70 & 5.93 & 4.50 & 4.72 & 1.73 & 17.05 & 0.62 & 0.16 & 48.41 & \\
\hline \multicolumn{11}{|c|}{ (b) Differences between observed landscape transitions and the expected gains (\%) } \\
\hline Agricultural land & 0.00 & 1.35 & -0.03 & 0.45 & -0.08 & 0.67 & -0.06 & -0.03 & 2.28 & 2.28 \\
\hline $\begin{array}{l}\text { Scattered } \\
\text { woodlan }\end{array}$ & 2.62 & 0.00 & -0.10 & 1.33 & 0.65 & 2.30 & 0.05 & -0.05 & 6.80 & 6.80 \\
\hline Bare land (BL) & -0.05 & -0.01 & 0.00 & -0.12 & -0.03 & 1.48 & 0.01 & -0.01 & 1.28 & 1.28 \\
\hline Bush/Shrub land (BS) & 3.16 & 1.05 & 0.02 & 0.00 & -0.08 & 0.66 & -0.04 & -0.03 & 4.73 & 4.73 \\
\hline $\begin{array}{l}\text { Dense acacia woodland } \\
\text { (DA) }\end{array}$ & 0.23 & 0.36 & -0.06 & -0.08 & 0.00 & 0.08 & 0.11 & -0.01 & 0.64 & 0.64 \\
\hline Grass/Grazing land (GL) & -0.73 & -0.42 & 0.44 & 0.23 & -0.16 & 0.00 & -0.05 & -0.02 & -0.71 & -0.71 \\
\hline $\begin{array}{c}\text { Swampy/Marshy land } \\
\text { (SM) }\end{array}$ & -0.30 & 0.03 & -0.05 & -0.15 & 0.23 & 0.00 & 0.00 & 0.15 & -0.09 & -0.09 \\
\hline Water body (WB) & -4.93 & -2.37 & -0.23 & -1.66 & -0.53 & -5.19 & -0.02 & 0.00 & -14.93 & -14.93 \\
\hline Total 2016 & 0.00 & 0.00 & 0.00 & 0.00 & 0.00 & 0.00 & 0.00 & 0.00 & 0.00 & 0.00 \\
\hline Gain & 0.00 & 0.00 & 0.00 & 0.00 & 0.00 & 0.00 & 0.00 & 0.00 & 0.00 & \\
\hline
\end{tabular}




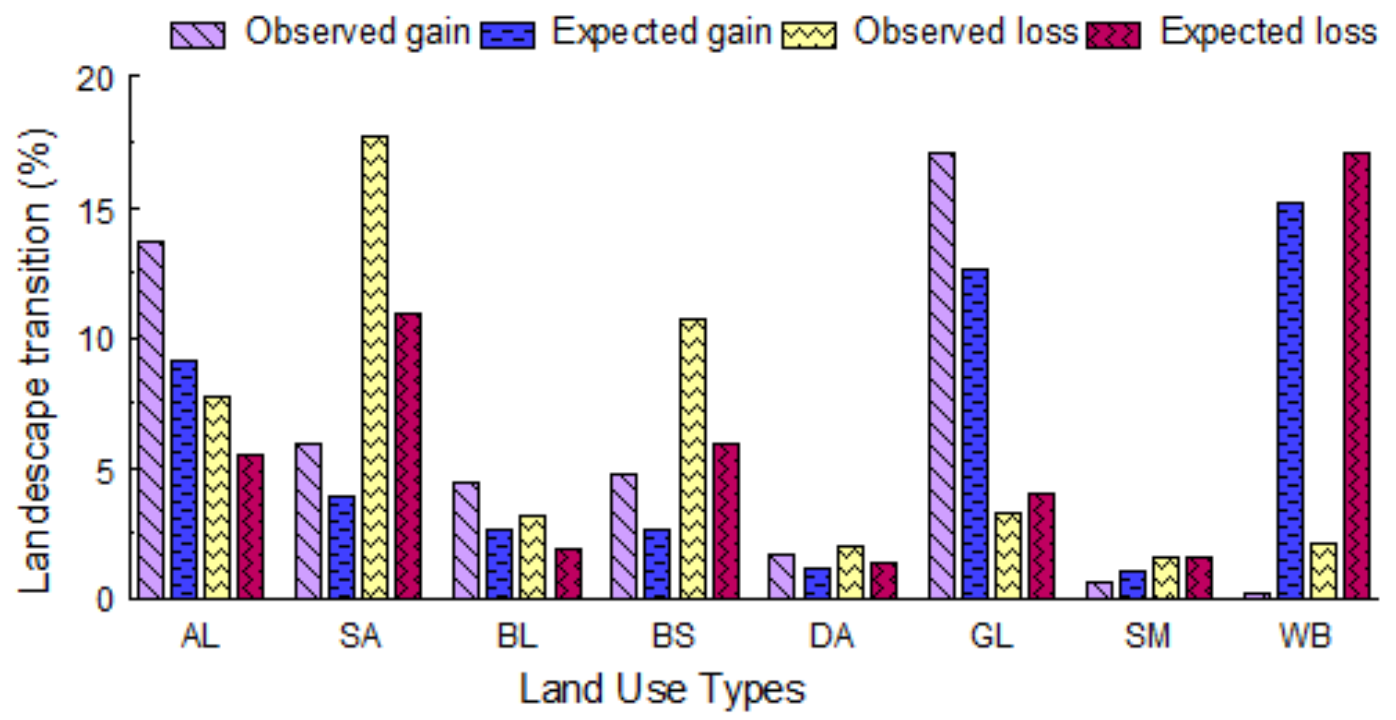

Figure 5. Observed and expected LULC gross gains and losses for 1986-2016 (\%): $A L=$ agricultural land, $S A=$ scattered acacia woodland, $B L=$ bare land, $B S=$ bush/shrub land, $D A$ $=$ dense acacia woodland, $G L=$ grass/grazing land, $S M=$ swampy/marshy land, and $W B=$ water body

The values for expected losses under a random process of loss are given in Table $8 a$, whereas the differences between the observed and expected losses are given in Table $8 b$. Relatively large positive values $(>0)$ in Table $8 b$ indicate systematic loss transitions. Accordingly, scattered acacia woodland systematically loses to agricultural land $(\mathbf{2 . 3 1} \%)$, grazing land $(\mathbf{1 . 7 4 \%})$ and bush land classes $(\mathbf{1 . 3 7 \%})$. Similarly bush land systematically loses to agricultural land $\mathbf{( 2 . 8 0 \% )}$, agricultural land systematically loses to scattered acacia woodland $(\mathbf{1 . 3 5} \%)$, bare land systematically loses to grazing land $(\mathbf{1 . 3 7 \%})$ and water body systematically loses to bare land $(\mathbf{1 . 0 7} \%)$. On the other hand, scattered acacia woodland, bush land, agricultural land and grazing land systematically avoided losing to water bodies which is indicated by relatively large and negative values in Table $8 b$.

In general, major interclass systematic gains and losses observed for this study can be summarized as follows (Fig. 4 and Table 5). About $6 \%$ of scattered acacia woodland and $5 \%$ of bush land has been converted to agricultural land, whereas about $7 \%$ and $3 \%$ of scattered acacia woodland has been respectively degraded and shifted to grazing land and bush/shrub lands during the study period. On the other hand, there has been an increase in vegetation biomass from agricultural land and bush land to scattered acacia woodland in over $2 \%$ of the landscape from each class. Similarly, there has been a vegetation restoration from bare land to grass land via ecological succession on lake retreat areas in over $2 \%$ of the landscape during the study period.

\section{Discussions}

Our result indicated that there has been an increased pressure from anthropogenicinduced LULC dynamics in the study region during the last three decades. This is evidenced by substantial gains/losses observed for major LULC categories during the 
study period (Table 4). For instance, expansion in agricultural land, grazing land and bare land by $124 \%, 42 \%$ and $34 \%$ respectively are among the changes attributed to gain, whereas decline in acacia woodlands and bush/shrub lands by $52 \%$ and $50 \%$ respectively are the major changes attributed to loss. Gain in grazing land is mainly due to land transition from lake retreat bare lands, particularly of Lake Abijata, that gradually shifts to grass/grazing land through ecological succession (Biazin and Sterk, 2013; Temesgen et al., 2013). With current rate of retreat, studies predicted that Lake Abijata will totally dry within coming 50 years (Temesgen et al., 2013). The other probable source for gain in grazing land is that in most cases acacia woodlands have been subjected to free access of firewood extraction and charcoal making by the community in rural Ethiopia, which gradually degrade the trees and shifts the land to either bush/shrub lands or open grazing areas. Coupled with natural pressures (frequent draught and fragile ecosystems), overgrazing is one basic proximate forcing factor behind high land degradation (critical water and wind erosion) observed during field work in CRV lakes region.

Table 8. LULC transition matrix for inter-class losses

\begin{tabular}{|c|c|c|c|c|c|c|c|c|c|c|}
\hline \multirow[b]{2}{*}{1986} & \multicolumn{10}{|c|}{2016} \\
\hline & $\mathbf{A L}$ & SA & BL & BS & DA & GL & SM & WB & $\begin{array}{l}\text { Total } \\
1986\end{array}$ & Loss \\
\hline \multicolumn{11}{|c|}{ (a) Expected losses under a random process of loss (\%) } \\
\hline Agricultural land (AL) & 6.15 & 1.08 & 0.49 & 0.58 & 0.22 & 2.41 & 0.20 & 2.82 & 13.94 & 7.79 \\
\hline $\begin{array}{l}\text { Scattered acac } \\
\text { woodland (SA }\end{array}$ & 3.96 & 5.15 & 1.01 & 1.18 & 0.44 & 4.95 & 0.41 & 5.77 & 22.87 & 17.72 \\
\hline Bare land (BL) & 0.67 & 0.37 & 0.59 & 0.20 & 0.08 & 0.84 & 0.07 & 0.98 & 3.79 & 3.21 \\
\hline Bush/Shrub land & 2.26 & 1.26 & 0.58 & 1.20 & 0.25 & 2.82 & 0.23 & 3.29 & 11.90 & 10.70 \\
\hline $\begin{array}{c}\text { Dense acacia woo } \\
\text { (DA) }\end{array}$ & 0.40 & 0.22 & 0.10 & 0.12 & 0.50 & 0.50 & 0.04 & 0.58 & 2.48 & 1.97 \\
\hline $\begin{array}{r}\text { Grass /Grazi } \\
\text { (GL) }\end{array}$ & 0.87 & 0.49 & 0.22 & 0.26 & 0.10 & 7.76 & 0.09 & 1.27 & 11.06 & 3.30 \\
\hline $\begin{array}{c}\text { Swampy/Mars } \\
\text { (SM) }\end{array}$ & 0.31 & 0.17 & 0.08 & 0.09 & 0.04 & 0.39 & 1.44 & 0.46 & 2.99 & 1.54 \\
\hline Water bod & 0.61 & 0.34 & 0.16 & 0.18 & 0.07 & 0.76 & 0.06 & 28.80 & 30.97 & 2.17 \\
\hline Tot: & 15.22 & 9.08 & 3.23 & 3.81 & 1.69 & 20.43 & 2.56 & 43.97 & 100.00 & 48.41 \\
\hline Gain & 9.08 & 3.93 & 2.65 & 2.61 & 1.19 & 12.67 & 1.11 & 15.17 & 48.41 & \\
\hline \multicolumn{11}{|c|}{ (b) Differences between observed landscape transitions and the expected losses (\%) } \\
\hline Agricultural land (AL) & 0.00 & 1.35 & 0.13 & 0.62 & -0.05 & 0.93 & -0.17 & -2.82 & 0.00 & 0.00 \\
\hline $\begin{array}{c}\text { Scattered acacia } \\
\text { woodland (SA) }\end{array}$ & 2.31 & 0.00 & -0.05 & 1.37 & 0.61 & 1.74 & -0.21 & -5.77 & 0.00 & 0.00 \\
\hline Bare land (BL) & -0.11 & -0.09 & 0.00 & -0.12 & -0.03 & 1.37 & -0.03 & -0.98 & 0.00 & 0.00 \\
\hline Bush/Shrub land (BS) & 2.80 & 0.71 & 0.00 & 0.00 & -0.13 & 0.12 & -0.20 & -3.29 & 0.00 & 0.00 \\
\hline $\begin{array}{l}\text { Dense acacia woodland } \\
\text { (DA) }\end{array}$ & 0.23 & 0.33 & -0.04 & -0.07 & 0.00 & 0.06 & 0.08 & -0.58 & 0.00 & 0.00 \\
\hline $\begin{array}{c}\text { Grass land/Grazing land } \\
\text { (GL) }\end{array}$ & 0.16 & -0.05 & 0.74 & 0.56 & -0.06 & 0.00 & -0.07 & -1.27 & 0.00 & 0.00 \\
\hline $\begin{array}{c}\text { Swampy/Marshy land } \\
\text { (SM) }\end{array}$ & -0.14 & 0.08 & 0.01 & -0.09 & 0.25 & 0.18 & 0.00 & -0.30 & 0.00 & 0.00 \\
\hline Water body (WB) & -0.60 & -0.33 & 1.07 & -0.18 & -0.05 & -0.01 & 0.12 & 0.00 & 0.00 & 0.00 \\
\hline Total 2016 & 4.63 & 1.99 & 1.85 & 2.11 & 0.54 & 4.39 & -0.49 & -15.01 & 0.00 & 0.00 \\
\hline Gain & 4.63 & 1.99 & 1.85 & 2.11 & 0.54 & 4.39 & -0.49 & -15.01 & 0.00 & \\
\hline
\end{tabular}


Agricultural land expansion in the region on the other hand is mainly in expense of losses in acacia woodlands and bush/shrub lands. Gain in agricultural land is associated with continual expansion of agricultural frontier as population increase (Garedew et al., 2009; Ariti et al., 2015), as population growth is the main underlying driver behind LULC change in developing countries like sub-Saharan Africa (Braimoh, 2006; Ouedraogo et al., 2011). This indicates agricultural land, bush/shrub land as well as grazing land targeted mainly the peculiar acacia woodland vegetation of the region for their gains. The result is in consistent with the results of previous LULC change studies in the region (Biazin and Sterk, 2013; Temesgen et al., 2013; Ariti et al., 2015) who reported agricultural land expansion as root cause for woodland vegetation decline in the region. Study by Zewdie and Csaplovics (2016) in dry lands of north western Ethiopia, an area with comparable agro ecological condition, also reported similar results. However, study by Braimoh (2006) and Ouedraogo et al. (2011) in western SubSaharan Africa reported decline in closed woodland mainly due to logging activities than due to crop land expansion. These studies also reported the systematic conversion of grazing land to crop land which is different from the case of our study. The loss in agricultural land observed for this study might be due to fallowing and abandonment of highly degraded farm lands as confirmed during field verification.

The other principal LULC change observed for this study is the substantial loss in acacia woodlands and bush/shrub land of the region (Table 4). Proximate causes for loss in scattered acacia woodland and bush/shrub land is most likely deforestation for firewood, charcoal making, and cultivation land expansion, owing to population pressure, and partly due to recent agricultural investment expansion in the region (Biazin and Sterk, 2013; Temesgen et al., 2013). The government of Ethiopia targeted the CRV lakes region as one potential agricultural investment zone due to its accessible lake water for irrigation and the proximity to Addis Ababa for ease of agricultural products export. Overgrazing pressure from pastoralist herds seasonally coming from neighbouring Districts in search of pasture grass is also another main factor for degradation of both woodlands and bush/shrub lands. Slight gain observed in scattered acacia woodland on the other hand could be associated with either degradation of dense acacia woodlands or government rehabilitation initiatives of degraded lands from either abandon agricultural lands or bush/shrub lands through area closure in recent years. This indicates part of the degraded and abandoned agricultural lands could shift to scattered acacia woodlands, following regeneration of remnant acacia trees after rehabilitation treatment like area closure. Currently the government has given strong attention to implement degraded land rehabilitation program, mainly through social mobilization, throughout the country though such practices are criticized for effectiveness and sustainability in most cases.

Analysis for changes attributed to persistence, net change and swap was another objective for this study. Results indicated that changes at landscape level are more attributed to swap (57\% of total change) than to net change (43\% of total change). However, the majority of LULC classes showed the tendency to persist (52\%) than to change during the same period (Table 4 and Fig. 4). Persistence is the resistance of the landscape to resist change and it usually dominates most landscape changes (Pontius et al., 2004). In line to this fact, our result also showed that the majority of the landscape area persisted than to change. It is normal to see more persistence than change in LULC change analysis (Pontius et al., 2004). Our result also showed that the overall percent 
change attributed to location (swap) is greater than the change attributed to net change at landscape level. This indicates the importance of analyzing swap beyond net change analysis in order to see the changes attributed to location which otherwise overlooked by 'net change' analysis alone (Pontius et al., 2004; Braimoh, 2006).

Finally, our result also identified systematic and random LULC changes occurred during the study period by comparing the observed change to the expected change arising from chance for any given degree of persistence (Table $7 b$ and $8 b$ ). Accordingly, the gain in agricultural land from scattered acacia wood land and bush/shrub land is systematic. This implies when agricultural land gains, new agricultural land tends to gain systematically from these classes (Braimoh, 2006). Similarly, scattered acacia woodland systematically gained from agricultural lands and bush/shrub lands; and both bush/shrub land and grazing lands systematically gained from scattered acacia woodland. This implies there is a systematic exchange of land portion among some LULC classes. On the other hand, the scattered acacia woodland systematically losing to agricultural land, bush/shrub land and grazing lands, whereas by reverse, agricultural land systematically losing to scattered acacia woodlands. In addition, bush/shrub lands systematically losing to agricultural land, and water body systematically losing to bare land. All the rest gain/loss observed in this study is depicted as random changes. However, it should be noted that a change is random does not necessarily downplay its worth as factors for random change could also lead to systematic change and vice versa (Braimoh, 2006). Figure 5 shows that the observed value for gain/loss is greater than the corresponding expected value for all land classes, except for swampy/marshy and water body. According to Braimoh (2006), the expected gain or loss could be different from the observed gain or loss due to various reasons: like changes in spatial determinants of land use distribution, such as population growth, soil suitability and the opening up of new roads, or it could be due to competition between LULC types.

This study might have limitations, for instance by using Landsat data, changes that are below pixel size might have been missed. Hence, in order to generate more information from the method, first, it is important to use algorithms that reduce map errors (Verburg et al., 2004; Alba, 2014; Agarwal et al., 2002) as accuracy assessment alone may not warrant for absence of map errors. For example, it is recommended to use other modeling algorithms like agent based modeling and spatial land change models for better results. Second, it might be important performing the method at multiple map resolutions in order to measure the sensitivity of the results to changes in map scale (Pontius et al., 2004). In addition, the similarity in spectral signature of some LULC classes could be another source of classification error in this study.

\section{Conclusions}

This study followed an approach that moves from broad to more detailed level of analysis and tried to highlight the importance of an in depth analysis of systematic and random LULC transition beyond the conventional net change analysis. It also indicated the importance of focusing on most prevalent systematic process of land change. Hence, future studies in the fields of geography and landscape ecology need to incorporate this method since existing popular methods fail to segregate LULC change according to its different components and thus fail to gain maximum insight in to the processes driving these changes. 
Our result clearly shown that, there have been active LULC dynamics in CRV lakes region of Ethiopia for the period of 1986 to 2016. From the concrete data of systematic gains and losses, we conclude that there have been most dominant and prominent signals of change in terms of conversion, degradation and restoration of LULC in CRV lakes region of Ethiopia. The majority of land conversion as well as degradation signals targeted the acacia woodlands of the region. To arrive at a conclusive evidence of a dominant signal of landscape transformation, class 1 must systematically gain from class 2 , and class 2 must systematically lose to class 1 simultaneously. Accordingly, the conversion of both scattered acacia woodlands and bush/shrub lands to agricultural land; the degradation of scattered acacia woodlands towards bush/shrub lands and grass/grazing lands; and the restoration in vegetation biomass from agricultural land and bare land towards scattered acacia woodland and grazing land respectively are found to be clearly systematic, and hence indicates the dominant signals of landscape transformation in this study. All the rest transitions are found to be either random or not fully systematic.

The result of this study implicates the continued land degradation in developing countries, particularly East Africa, where the livelihood of the majority of population is directly dependent on natural resources. The loss in acacia woodlands and bush/shrub lands either by conversion or through degradation, calls for means to reduce such adverse pressures. The decline in water bodies and shift to bare land, particularly of Lake Abijata, requires urgent watershed management measures on its catchment area. Increased land use intensity due to increased population pressure calls for agricultural intensification related policies to prevent crop land expansion on fragile lands. The pressure on woodlands from firewood extraction and charcoal making requires availing affordable alternative energy source technologies to poor households. The restoration in vegetation biomass requires further study to know where and how it occurs, how long it takes and factors underlying it. Future studies also need to investigate the local and national level drivers behind; and the impacts imposed by such continued LULC changes to rural livelihood, natural ecosystem and biodiversity in the region. In general, future land use policies need to consider such prominent signals of land change in order to plan an integrated approach to safeguard the fragile acacia woodland ecosystems while searching for alternative livelihood options to feed the ever growing population in the region.

Acknowledgements. The authors are indebted to thank the National Natural Sciences Foundation of China (Fund No. 41571176) and The 111 Project (Fund No. B17024) by State Administration of Foreign Experts Affairs and Ministry of Education of China for financial support and encouragement in conducting this study. We are grateful to thank the Chinese government Scholarship Council (CSC) for giving a chance for the first author to pursue his $\mathrm{PhD}$ study in China. Special thanks also go to all the staff members of Agricultural Office of the Dugda, Adami Tulu-Jido Kombolcha and Arsi Negele districts who helped during field data collection and all the rural farmers of the three districts who took part during the survey. We are also grateful to thank the anonymous reviewers for their helpful comments and suggestions on earlier draft of this manuscript.

\section{REFERENCES}

[1] Abdelkadir, A., Yimer, F. (2011): Soil water property variations in three adjacent land use types in the Rift Valley area of Ethiopia. - Journal of Arid Environments 75(11): 1067-1071. 
[2] Agarwal, C., Green, G. M., Grove, J. M., Evans, T. P., Schweik, C. M. (2002): A Review and Assessment of Land-Use Change Models: Dynamics of Space, Time, and Human Choice, Vol. 297. - Citeseer Publishing, USA.

[3] Alba, G (2014): Remote Sensing Classification Alghoritms Analysis Applied to Land Cover Change. - Mario Gulich Institute, Argentina.

[4] Alo, C. A., Pontius Jr, R. G. (2008): Identifying systematic land-cover transitions using remote sensing and GIS: the fate of forests inside and outside protected areas of Southwestern Ghana. - Environment and Planning B: Planning and Design 35(2): 280295.

[5] Ariti, A. T., van Vliet, J., Verburg, P. H. (2015): Land-use and land-cover changes in the Central Rift Valley of Ethiopia: Assessment of perception and adaptation of stakeholders. - Appled Geography 65: 28-37.

[6] Benvenuti, M., Carnicelli, S., Belluomini, G., Dainelli, N., Di Grazia, S., Ferrari, G., Iasio, C., Sagri, M., Ventra, D., Atnafu, B. (2002): The Ziway-Shala lake basin (Main Ethiopian Rift, Ethiopia): a revision of basin evolution with special reference to the Late Quaternary. - Journal of African Earth Sciences 35(2): 247-269.

[7] Biazin, B., Sterk, G. (2013): Drought vulnerability drives land-use and land cover changes in the Rift Valley dry lands of Ethiopia. - Agr Ecosyst Environ 164: 100-113.

[8] Biazin, B., Stroosnijder, L., Temesgen, M., AbdulKedir, A., Sterk, G. (2011): The effect of long-term Maresha ploughing on soil physical properties in the Central Rift Valley of Ethiopia. - Soil \& Tillege Research 111(2): 115-122.

[9] Booth, D., Oldfield, R. (1989): A comparison of classification algorithms in terms of speed and accuracy after the application of a post-classification modal filter. - Remote Sensing 10(7): 1271-1276.

[10] Braimoh, A. K. (2006): Random and systematic land-cover transitions in northern Ghana. - Agriculture Ecosystems and Environ 113(1-4): 254-263.

[11] Braimoh, A. K., Vlek, P. L. (2005): Land-cover change trajectories in Northern Ghana. Environmental Management 36(3): 356-373.

[12] Briones, P. S., Sepúlveda-Varas, A. (2017): Systematic transitions in land use and land cover in a pre-Andean subwatershed with high human intervention in the Araucania Region, Chile. - Cienc Investig Agrar 43(3): 396-407.

[13] Burmeister, C., Schanze, J. (2016): Retrospective analysis of systematic land-cover change in the upper western Bug River Catchment, Ukraine. - ACC Journal 22(1): 7-18.

[14] CSA (1994, 2007): The 1994 and 2007 Population and Housing Census Results for Oromiya Region. - Central Statistical Authority, Addis Ababa, Ethiopia.

[15] Dessie, G., Kleman, J. (2007): Pattern and magnitude of deforestation in the South Central Rift Valley Region of Ethiopia. - Mountain Research and Development 27(2): 162-168.

[16] Eshetu, A. A. (2014): Forest resource management systems in Ethiopia: Historical perspective. - International Journal of Biodiversity and Conservation 6(2): 121-131.

[17] FAO (2016): State of the World's Forests 2016: Forests and Agriculture: Land-Use Challenges and Opportunities. - FAO, Rome.

[18] Fritzsche, F., Zech, W., Guggenberger, G. (2007): Soils of the Main Ethiopian Rift Valley escarpment: A transect study. - Catena 70(2): 209-219.

[19] Garedew, E., Sandewall, M., Soderberg, U., Campbell, B. M. (2009): Land-use and landcover dynamics in the central rift valley of Ethiopia. - Environmental Management 44(4): 683-694.

[20] Geist, H., McConnell, W., Lambin, E. F., Moran, E., Alves, D., Rudel, T. (2006): Causes and Trajectories Of Land-Use/Cover Change. - In: Lambin, E. F., Geist, H. (ed.) LandUse and Land-Cover Change: Local Process and Global Impacts, pp. 41-70. SpringerVerlag, Berlin, Germany.

[21] Geist, H. J., Lambin, E. F. (2002): Proximate causes and underlying driving forces of tropical deforestation. - BioScience 52(2): 143-150. 
[22] Hall, F. G., Strebel, D. E., Nickeson, J. E., Goetz, S. J. (1991): Radiometric rectification: toward a common radiometric response among multidate, multisensor images. - Remote Sensing of Environment 35(1): 11-27.

[23] Hengsdijk, H., Jansen, H. (2006): Agricultural Development in the Central Ethiopian Rift Valley: A Desk-Study on Water-Related Issues and Knowledge to Support a Policy Dialogue. - Plant Research International BV, Wageningen.

[24] Itanna, F. (2005): Sulfur distribution in five Ethiopian Rift Valley soils under humid and semi-arid climate. - Journal of Arid Environments 62(4): 597-612.

[25] Jansen, H., Hengsdijk, H., Legesse, D., Ayenew, T., Hellegers, P., Spliethoff, P. (2007): Land and Water Resources Assessment in the Ethiopian Central Rift Valley: Project: Ecosystems for Water, Food and Economic Development in the Ethiopian Central Rift Valley. - Alterra-raport 1587, Alterra, Wageningen.

[26] Jensen, J. R. (1996): Introductory Digital Image Processing: A Remote Sensing Approach, Vol. 7458. - Prentice Hall, Upper Saddle River, NJ.

[27] JICA (2012): The Study on Groundwater Resources Assessment in the Rift-Valley Lakes Basin in the Federal Democratic Republic of Ethiopia (Main and Final Report). - Japan International Cooperation Agency (Kokusai Kogyo C. O., LTD), Tokyo.

[28] Kalacska, M., Arroyo-Mora, J. P., Lucanus, O., Kishe-Machumu, M. A. (2017): Land cover, land use, and climate change impacts on Endemic Cichlid Habitats in Northern Tanzania. - Remote Sensing 9(6): 623.

[29] Kindu, M., Schneider, T., Teketay, D., Knoke, T. (2013): Land use/land cover change analysis using object-based classification approach in Munessa-Shashemene Landscape of the Ethiopian Highlands. - Remote Sensing 5(5): 2411-2435.

[30] Lambin, E. F. (1997): Modelling and monitoring land-cover change processes in tropical regions. - Progress in Physical Geography 21(3): 75-393.

[31] Lambin, E. F., Geist, H. J., Lepers, E. (2003): Dynamics of land-use and land-cover change in tropical regions. - Annu. Rev. Environ. Resour. 28(1): 205-241.

[32] Lemenih, M., Kassa, H. (2014): Re-greening Ethiopia: history, challenges and lessons. Forests 5(8): 1896-1909.

[33] Li, J., Zhang, Y., Qin, Q., Yan, Y. (2017): Investigating the impact of human activity on land use/cover change in China's Lijiang River Basin from the perspective of flow and type of population. - Sustainability 9(3): 383.

[34] Lillesand, T., Kiefer, R. W., Chipman, J. (2014): Remote Sensing and Image Interpretation. - John Wiley \& Sons, New York.

[35] Liu, H., Zhou, Q. (2004): Accuracy analysis of remote sensing change detection by rulebased rationality evaluation with post-classification comparison. - International Journal of Remote Sensing 25(5): 1037-1050.

[36] Manandhar, R., Odeh, IO. A., Pontius, R. G. (2010): Analysis of twenty years of categorical land transitions in the Lower Hunter of New South Wales, Australia. Agriculture, Ecosystems \& Environment 135(4): 336-346.

[37] MEA (2005): Ecosystems and Human Well-Being: Synthesis. - Island Press, Washington, DC.

[38] Meire, E., Frankl, A., De Wulf, A., Haile, M., Deckers, J., Nyssen, J. (2013): Land use and cover dynamics in Africa since the nineteenth century: warped terrestrial photographs of North Ethiopia. - Regional Environmental Change 13(3): 717-737.

[39] Melka, Y., Kassa, H., Ketema, M., Abebaw, D., Schmiedel, U. (2015): The effect of drought risk perception on local people coping decisions in the Central Rift Valley of Ethiopia. - Journal of Development and Agricultural Economics 7(9): 292-302.

[40] Meshesha, D. T., Tsunekawa, A., Tsubo, M., Ali, S. A., Haregeweyn, N. (2014): Landuse change and its socio-environmental impact in Eastern Ethiopia's highland. - Regional Environmental Change 14(2): 757-768.

[41] Molin, P., Corti, G. (2015): Topography, river network and recent fault activity at the margins of the Central Main Ethiopian Rift (East Africa). - Tectonophysics 664: 67-82. 
[42] Muzein, B. S. (2006): Remote sensing \& GIS for land cover/land use change detection and analysis in the semi-natural ecosystems and agriculture landscapes of the Central Ethiopian Rift Valley. - PhD Dissertation, Technology University of Dresden, Germany.

[43] Nagendra, H., Munroe, D. K., Southworth, J. (2004): From pattern to process: landscape fragmentation and the analysis of land use/land cover change. - Agriculture, Ecosystems \& Environment 101(2-3): 111-115.

[44] Ouedraogo, I., Savadogo, P., Tigabu, M., Dayamba, S. D., Odén, P. C. (2011): Systematic and random transitions of land-cover types in Burkina Faso, West Africa. International Journal of Remote Sensing 32(18): 5229-5245.

[45] Pontius, R. G., Shusas, E., McEachern, M. (2004): Detecting important categorical land changes while accounting for persistence. - Agriculture, Ecosystems \& Environment 101(2-3): 251-268.

[46] Rai, R., Zhang, Y., Paudel, B., Li, S., Khanal, N. (2017): A synthesis of studies on land use and land cover dynamics during 1930-2015 in Bangladesh. - Sustainability 9(11): 1866.

[47] Reid, R. S., Kruska, R. L., Muthui, N., Taye, A., Wotton, S., Wilson, C. J., Mulatu, W. (2000): Land-use and land-cover dynamics in response to changes in climatic, biological and socio-political forces: the case of southwestern Ethiopia. - Landscape Ecology 15(4): 339-355.

[48] Singh, A. (1989): Digital change detection techniques using remotely-sensed data. International Journal of Remote Sensing 10(6): 989-1003.

[49] Temesgen, H., Nyssen, J., Zenebe, A., Haregeweyn, N., Kindu, M., Lemenih, M., Haile, M. (2013): Ecological succession and land use changes in a lake retreat area (Main Ethiopian Rift Valley). - Journal of Arid Environments 91: 53-60.

[50] Tucker, C. J., Dregne, H. E., Newcomb, W. W. (1991): Expansion and contraction of the Sahara Desert from 1980 to 1990. - Science 253(5017): 299-301.

[51] Verburg, P. H., Schot, P. P., Dijst, M. J., Veldkamp, A. (2004): Land use change modelling: current practice and research priorities. - GeoJournal 61(4): 309-324.

[52] Versace, V. L., Ierodiaconou, D., Stagnitti, F., Hamilton, A. J. (2008): Appraisal of random and systematic land cover transitions for regional water balance and revegetation strategies. - Agriculture, Ecosystems \& Environment 123(4): 328-336.

[53] Wijedasa, L. S., Sloan, S., Michelakis, D. G., Clements, G. R. (2012): Overcoming limitations with Landsat imagery for mapping of peat swamp forests in Sundaland. Remote Sensing 4(9): 2595-2618.

[54] Yan, F., Zhang, S., Liu, X., Chen, D., Chen, J., Bu, K., Yang, J., Chang, L. (2016): The effects of spatiotemporal changes in land degradation on ecosystem services values in Sanjiang Plain, China. - Remote Sensing 8(11): 917.

[55] Yirsaw, E., Wu, W., Shi, X., Temesgen, H., Bekele, B. (2017): Land use/land cover change modeling and the prediction of subsequent changes in ecosystem service values in a coastal area of China, the Su-Xi-Chang Region. - Sustainability 9(7): 1204.

[56] Zewdie, W., Csaplovics, E. (2016): Identifying categorical land use transition and land degradation in northwestern Drylands of Ethiopia. - Remote Sensing 8(5): 408.

[57] Zhang, C., Chen, Y., Lu, D. (2015): Mapping the land-cover distribution in arid and semiarid urban landscapes with Landsat Thematic Mapper imagery. - International Journal of Remote Sensing 36(17): 4483-4500. 